\title{
Disentangling the links between conservation and poverty reduction in practice
}

\author{
Matt Walpole and Lizzie Wilder
}

\begin{abstract}
Biodiversity conservation is increasingly expected to reduce poverty where the two coincide. Yet conservation and poverty are multifaceted concepts and the linkages between them are complex and variable; whether and how conservation contributes to poverty reduction in practice will depend on the specific nature of those linkages. To unravel this complexity we explored the portfolio of Fauna \& Flora International, an international conservation organization operating in some of the poorest countries and regions. We examined reports from 88 projects and categorized the rationales, approaches and outcomes of a sample of 34 livelihoods-focused projects. Rationales varied among and within projects and included apparent 'win-win' scenarios (reducing poverty improves conservation outcomes), trade-offs (conservation action hurts the poor or poverty reduction damages biodiversity), and situations where livelihoods interventions were not directly linked to conservation gains. Projects revealed a balance of direct (income, food security, health) and indirect (capacity building, reduced vulnerability, governance, empowerment) livelihood goals. Overall, empowerment, security and social network development were more significant short-term outcomes than income generation. Social responsibility was widely embedded but does not necessarily translate into a positive impact on poverty. Conservation organizations have the potential to improve the lives of the poor in many places where they operate, and arguably a duty to ensure that conservation does not make poor people worse off. Yet it is important to be clear about the reasons for engaging and the scope and scale of likely outcomes.
\end{abstract}

Keywords Communities, conservation strategies, livelihoods, poverty, social impacts, trade-offs.

This paper contains supplementary material that can be found online at http://journals.cambridge.org

\footnotetext{
Matt Walpole* (Corresponding author) and Lizzie Wilder Fauna \& Flora International, Jupiter House, Station Road, Cambridge, CB1 2JD, UK. E-mail matt.walpole@unep-wcmc.org

${ }^{*}$ Current address: UNEP-WCMC, 219 Huntingdon Road, Cambridge, CB3 0DL, UK.

Received 6 May 2008. Revision requested 31 May 2008.

Accepted 2 July 2008.
}

\section{Introduction}

The extent to which biodiversity conservation can, does, I or should be expected to contribute to poverty reduction efforts has been the subject of vigorous debate (Roe, 2008). Some argue that it is inappropriate or ineffective for conservationists to attempt to address poverty issues and diverts attention and resources away from core conservation missions (Sanderson \& Redford, 2003, 2004; Kiss, 2004; Terborgh, 2004). Others imply that there is no choice but for conservation organizations to engage, for both ethical and pragmatic reasons (Roe \& Elliot, 2004, 2006; Kaimowitz \& Shiel, 2007).

Critiques of protected areas as engines of socioeconomic marginalization (Brockington \& Schmidt-Soltau, 2004; Lockwood et al., 2006) and of conservation NGOs as corporations riding roughshod over human rights (Chapin, 2004), alongside a shift in donor funding away from environmental matters and towards poverty reduction (Roe, 2008), has led to a scramble within parts of the conservation community to demonstrate its pro-poor credentials and its relevance to the international poverty reduction agenda. At both the World Parks Congress (in 2003) and World Conservation Congress (in 2004), resolutions were passed that urged conservationists and protected area managers to ensure conservation is of benefit to the poor, and similar proposals are being developed for the Convention on Biological Diversity (Mapendembe et al., 2008). Conservationists are increasingly promoting the argument that biodiversity underpins poverty reduction because of the importance of natural resources to the livelihoods and well-being of the poor (Ash \& Jenkins, 2007), and highlighting cases where conserving threatened biodiversity benefits the poor (WWF, 2006).

Others are less sure. Case studies illustrating either the positive or negative social impacts of conservation abound, alongside broader scale analyses of the level of geographical association between poverty and areas of conservation priority (Gorenflo \& Brandon, 2006; de Sherbinin, 2008; Upton et al., 2008; Redford et al., 2008). Yet there remains little universal clarity over whether and in what ways conservation in practice could be a mechanism for reducing poverty.

One of the problems is that the academic debate and the analyses surrounding it often oversimplify the complexity inherent in the concepts of conservation and poverty (what conservation does, and what poverty is, are both very broad topics) and variation in the ways that they interact 
(Agrawal \& Redford, 2006). There may be good reasons for simplifying the arguments to create marketable messages for donors, policy makers and the general public. However, in a world of increasing accountability and public scrutiny such messages must still be based on fact and, in reality, poverty-conservation relationships are more complex. Conservation researchers and practitioners need to grapple with that complexity if the debate, and conservation performance, is to progress.

Numerous theoretical frameworks to categorize povertyconservation relationships exist (Nadkarni, 2000; Adams et al., 2004; Roe \& Elliot, 2005). These outline a range of rationales for conservationists to engage with the poor, which in turn dictate the approaches taken by practitioners and the likely outcomes, not all of which will necessarily reduce poverty (Table 1). This is not always understood, particularly amongst conservation biologists. To achieve greater clarity we must disentangle the links by exploring how the rationales in these conceptual frameworks are played out in practice, and which elements of poverty are at the fore (Sunderlin et al., 2005; Robinson, 2006).

Using the portfolio of one international conservation organization, Fauna \& Flora International (FFI), as an example, this paper explores how, if at all, conservation activities may contribute to poverty reduction. We ask two principal and related questions. Firstly, what are the rationales being used at field level for engaging, or not engaging, with the poor? This is important because it dictates the extent to which conservation is likely to provide local benefits as opposed to simply offsetting costs. Secondly, which aspects of poverty are being addressed? Identifying which elements of poverty are most relevant to conservation in practice will help us focus our efforts and ensure we have the right skills to do it, the right research to evaluate impact, and the right arguments to put before critics, thereby improving conservation performance and impact.

\section{Methods}

Founded in 1903, FFI's mission is to '...conserve threatened species and ecosystems worldwide, choosing solutions that are sustainable, based on sound science and take account of human needs' (FFI, 2008a). FFI is active in c. 40 countries, developing, implementing and managing biodiversity conservation projects in partnership with host country organizations, to protect and conserve species and ecosystems using a genuinely participatory approach, based upon a strong commitment to building local capacities and to long-term sustainability of conservation achievements.

FFI's mission refers explicitly to human needs, and to address this it established a Biodiversity \& Human Needs thematic programme in 2004 'to reflect on how and why we are addressing human needs, to improve our monitoring and analysis of our achievements, and to develop good practice to ensure that we achieve our mission effectively and universally' (FFI, 2006).

\section{Analysis of a livelihoods portfolio}

Two main sources of internal FFI documentary information were used to explore livelihood linkages in FFI's work. Firstly, to assess the breadth of engagement with livelihoods and poverty issues, the entire set of annual reports from FFI projects for 2006 were examined $(n=88)$. The annual reporting instrument for 2006 was developed by ourselves and others to focus on outcomes, impacts and lessons learned, broken down into a series of conservation activity areas including livelihoods and human needs. It also asked project managers to record what they felt was the most significant achievement of their project during 2006.

Secondly, for a detailed understanding of project rationales and approaches, documents from a self-selected sample of 34 projects with a distinct livelihoods component directly supported by FFI's Biodiversity \& Human Needs programme during 2004-2007 were examined. Each of these projects was required to submit a detailed plan outlining its rationale for engaging with local livelihoods, its objectives and activities, and its intended outcomes and impacts for livelihoods and for conservation. Using these project plans, associated documentation (project profiles and biannual progress reports), and comprehensive internal evaluation reports submitted in early 2008, the following information was extracted: (1) Conservation focus: species, terrestrial landscape, marine, non-specific/ broader scale. (2) Rationale for engaging with livelihoods: using the five categories in Table 1. (3) Approach taken: whether direct, field-based livelihoods interventions (either linked to or uncoupled from biodiversity) or indirect institutional-strengthening and policy-related activities at local, national or international scales. (4) Livelihoods outcomes: planned or in some cases actual, using the UK Department for International Development's Sustainable Livelihoods framework (Appendix). (5) Role of livelihoods interventions in the context of the wider conservation strategy.

In addition to this documentary evidence, insights were gathered from site visits, interviews with project managers and a series of regional meetings during 2005-2007 where these projects were presented and discussed with other staff and partners.

It should be noted that this study does not seek to assess the success or failure of different approaches to poverty reduction in conservation projects. Whilst some insights are drawn from projects where outcomes could be demonstrated, in most projects it was too early to do so. The primary aim of this study was to explore the breadth of both the logical and operational links between poverty and conservation within FFI's portfolio, and what they mean, 
TABLE 1 Framework of rationales for engaging with poverty (adapted from Nadkarni, 2000; Adams et al., 2004; Roe \& Elliot, 2005) and their implications for conservation activities ${ }^{1}$, including frequency of occurrence of different rationales within a sample of 34 FFI livelihoods-focused projects, and some example projects from the same sample.

\begin{tabular}{|c|c|c|c|}
\hline $\begin{array}{l}\text { Rationale for } \\
\text { engaging with } \\
\text { poverty }\end{array}$ & Implications & $\begin{array}{l}\text { No. of projects } \\
\text { where main } \\
\text { rationale }^{2}\end{array}$ & Example projects \\
\hline $\begin{array}{l}\text { 1, Conservation } \\
\text { underpins } \\
\text { poverty } \\
\text { reduction }\end{array}$ & $\begin{array}{l}\text { Biodiversity provides ecosystem goods \& services } \\
\text { that, if conserved \& used sustainably, will } \\
\text { underpin livelihoods \& provide long-term } \\
\text { security \& resilience. This is the argument behind } \\
\text { the ecosystem approach to conservation \& implies } \\
\text { a passive, long-term contribution to poverty } \\
\text { reduction. }\end{array}$ & $2(13)$ & $\begin{array}{l}\text { Protecting or restoring forest habitat to improve } \\
\text { freshwater provision, the supply of traditionally } \\
\text { harvested non-timber forest products \& } \\
\text { ecotourism potential in Cambodia, Brazil \& } \\
\text { Nicaragua }\end{array}$ \\
\hline $\begin{array}{l}\text { 2, Poverty } \\
\text { reduction leads } \\
\text { to conservation }\end{array}$ & $\begin{array}{l}\text { Reducing poverty reduces pressure on biodiversity } \\
\text { by reducing the need for unsustainable use, } \\
\text { providing opportunities for alternative livelihoods } \\
\text { \& placing people in a position where they can } \\
\text { choose to conserve. This is the argument behind } \\
\text { integrated conservation \& development projects, } \\
\text { \& has resulted in conservationists becoming } \\
\text { actively involved in more immediate livelihoods- } \\
\text { focused initiatives. }\end{array}$ & 18 & $\begin{array}{l}\text { Support to alter \& improve agricultural practices } \\
\text { where they threaten natural forests \& critical } \\
\text { wildlife habitats in Belize, Ecuador \& Cambodia }\end{array}$ \\
\hline $\begin{array}{l}\text { 3, Conservation } \\
\text { hinders poverty } \\
\text { reduction }\end{array}$ & $\begin{array}{l}\text { Conservation inflicts costs on the poor that limit } \\
\text { their options \& ability to rise out of poverty. This } \\
\text { is the argument levelled in particular at protected } \\
\text { areas by some social commentators, \& can lead to } \\
\text { conservationists taking a moral position to 'do no } \\
\text { harm' \& attempting to offset the costs of } \\
\text { conservation through outreach \& benefit-sharing } \\
\text { programmes. }\end{array}$ & $8(13)$ & $\begin{array}{l}\text { Developing people-focused policies, participatory } \\
\text { management plans \& human-wildlife conflict } \\
\text { mitigation strategies for protected areas in } \\
\text { Mozambique, DRC \& Kenya }\end{array}$ \\
\hline $\begin{array}{l}\text { 4, Poverty } \\
\text { reduction } \\
\text { hinders } \\
\text { conservation }\end{array}$ & $\begin{array}{l}\text { Increased affluence \& opportunity, or an overtly } \\
\text { economic-oriented development policy, fuels } \\
\text { environmental degradation \& biodiversity loss. } \\
\text { This is the argument that environmentalists \& } \\
\text { conservationists have levelled at the development } \\
\text { lobby for decades \& is the principal fear of those } \\
\text { who see environmental concerns marginalized in } \\
\text { the race to meet the relatively short-term targets } \\
\text { of the Millennium Development Goals. }\end{array}$ & $5(10)$ & $\begin{array}{l}\text { Averting the transformation of fynbos habitat to } \\
\text { cultivation by promoting the development of } \\
\text { a market for sustainably-harvested wild flowers in } \\
\text { South Africa }\end{array}$ \\
\hline $\begin{array}{l}\text { 5, Poverty } \\
\text { reduction } \\
\text { generates } \\
\text { goodwill \& } \\
\text { trust }\end{array}$ & $\begin{array}{l}\text { Some projects address local priorities \& needs } \\
\text { even if they are not directly related to } \\
\text { conservation outcomes, to generate a local } \\
\text { constituency of support for conservation. } \\
\text { Livelihoods or poverty reduction interventions act } \\
\text { as an entry point \& mechanism to engender that } \\
\text { support at grass roots levels. This can be } \\
\text { extremely important given that the traditional } \\
\text { development bodies (government, aid agencies \& } \\
\text { the private sector) are often conspicuously lacking } \\
\text { in the poor, rural areas in which conservation } \\
\text { NGOs operate. Projects can find themselves either } \\
\text { taking the place of such traditional bodies, or } \\
\text { operating as a facilitator linking communities to } \\
\text { development opportunities. }\end{array}$ & $1(5)$ & $\begin{array}{l}\text { Supporting social enterprise development to } \\
\text { provide a platform for future conservation } \\
\text { engagement in Kyrgyzstan }\end{array}$ \\
\hline
\end{tabular}

\footnotetext{
${ }^{1}$ These various rationales are not necessarily mutually exclusive and may apply simultaneously in a particular place or situation, involving different people or between different elements of poverty and conservation and over different time-scales.

${ }^{2}$ Number in parentheses refers to total number of projects where rationale mentioned
} 
to help conservation researchers and practitioners refine their thinking.

\section{Results}

Of the 88 annual reports $>85 \%$ recorded some kind of engagement with local communities and poverty issues as part of their conservation activities. The more detailed analysis of 34 projects spanning 22 countries across four continents included some of the poorest places on earth (Appendix). The majority of projects focused on terrestrial landscape conservation $(n=21)$, with c. $25 \%$ being speciesfocused $(n=9)$. A minority of projects $(n=3)$ were unspecific, working indirectly at broader scales. Marine projects were underrepresented $(n=1)$. Differences in the rationale and approach of species projects versus landscape projects are identified below.

\section{Rationales underpinning project strategies and interventions}

In the majority of cases there was more than one rationale for engaging with livelihoods. Many projects were simultaneously attempting to reduce threats to biodiversity, offset costs for people locally, and increase support for conservation. However, reducing threats to biodiversity by improving livelihoods/reducing poverty (Rationale 2; Table 1) was the most common primary rationale, followed by offsetting the costs of conservation for local people (Rationale 3). A higher proportion of species (33\%) than landscape projects (19\%) adopted the latter.

The argument that conservation underpins poverty reduction (Rationale 1) was used exclusively in relation to the provision of ecosystem goods, i.e. the sustainable use of elements of biodiversity by the poor (through tourism or consumptive use), rather than in relation to the provision of supporting/regulating ecosystem services and ecological resilience.

The argument that poverty reduction threatens conservation efforts (Rationale 4) was used primarily in response to the planned activities of governments and development agencies that risked overlooking environmental concerns in the face of economic or humanitarian expediency. It was less related to fears of over-consumption with increased affluence as a result of poverty reduction, although this could become an issue in some cases in the future. Some projects recognized that external (rather than local) consumer demand was a driver of biodiversity decline but had no direct means to address it.

Few projects appeared to be using an indirect rationale for livelihoods interventions as a means of entry and engagement with poor rural communities to generate a constituency of support (Rationale 5). However, when rationales were discussed at a workshop session with one of FFI's regional teams, this was considered to be a much more common reason for engaging with livelihoods than is often recognized or written in funding proposals.

\section{Approaches used in engaging with local livelihoods and poverty}

The full spectrum of approaches was illustrated across the portfolio, and several $(\mathrm{n}=8)$ involved multiple strategies, combining direct (field-based) and indirect (institutional and policy-related) approaches. However, most projects appeared to focus on direct interventions $(n=18)$, with c. $25 \%(\mathrm{n}=8)$ taking only indirect approaches. Of the latter, local institutional strengthening was more common than policy interventions.

Amongst direct interventions there was an even balance of projects aiming to strengthen existing livelihoods (mainly agriculture and pastoralism), provide alternative livelihoods not linked to the landscape or species of conservation concern (mainly agriculture/agroforestry), and provide alternative livelihoods based on sustainable extractive use of the biodiversity in question (mainly plants or plant parts). Nature-based tourism as a non-consumptive linked livelihood only featured in a minority of projects, most of which were species-focused (Table 2).

\section{Poverty reduction and livelihoods outcomes}

A wide range of livelihoods effects were anticipated across the portfolio (Table 3). The most common impacts were on human skills and social networks as a result of the training, capacity building, network development and facilitation that projects undertake. It was less common for projects to invest directly in the more tangible natural, physical or financial assets, although a minority did provide infrastructure, access to loans or micro-finance, or greater access to natural resources. About $30 \%$ of projects focused on influencing structures and processes (building organizational capacity and developing appropriate policies), and a similar proportion aimed to increase local empowerment, mainly through participatory approaches to increase local engagement in conservation decision making. In terms of livelihoods outcomes, there was an even spread of attention to income, food security, sustainable resource management and reduced vulnerability.

More detailed evaluation of actual outcomes from a number of these projects revealed evidence that responding to local needs (such as food, water and land tenure), improving institutional and policy environments and enhancing local capacity and empowerment served to reduce local vulnerability in a variety of ways (Table 4 ). Furthermore these had tangible conservation benefits by stimulating local action to reduce threats to biodiversity. Although just under $50 \%$ of all projects included increased 
TABLE 2 Frequency of occurrence of different approaches to engaging directly with livelihoods and poverty reduction within a sample of 34 FFI livelihoods-focused projects.

\begin{tabular}{|c|c|c|}
\hline Type of direct livelihoods approach & $\begin{array}{l}\text { No. of } \\
\text { projects }\end{array}$ & Project examples \\
\hline Strengthen existing livelihoods & 11 & $\begin{array}{l}\text { Improving rice farming techniques to reduce food insecurity } \\
\text { in Cambodia }\end{array}$ \\
\hline Alternative linked livelihood (tourism) & 5 & $\begin{array}{l}\text { Developing community involvement in Pemba flying fox } \\
\text { Pteropus voeltzkowi tourism in Zanzibar }\end{array}$ \\
\hline Alternative linked livelihood (sustainable use) & 12 & $\begin{array}{l}\text { Implementing sustainable management of native fruit \& nut } \\
\text { forests in Kyrgyzstan }\end{array}$ \\
\hline Alternative non-linked livelihoods & 12 & $\begin{array}{l}\text { Supporting small, service-based enterprises as alternatives to } \\
\text { saiga Saiga tatarica poaching in Kazakhstan }\end{array}$ \\
\hline Multiple livelihoods strategies & 8 & $\begin{array}{l}\text { Influencing national government forest policy, diversifying } \\
\text { local farming \& building capacity for community-forest } \\
\text { management in Liberia }\end{array}$ \\
\hline No direct livelihoods strategies & 3 & $\begin{array}{l}\text { Raising awareness of conservation-poverty linkages } \\
\text { amongst NGOs in the Philippines }\end{array}$ \\
\hline
\end{tabular}

income as a likely outcome, only $10 \%$ were able to demonstrate this within the time-frame of the study.

Across FFI's wider project portfolio $>33 \%$ of project managers reported that their most significant project achievements in 2006 related to work supporting local communities. These fell into three broad categories: (1) changing government perceptions to accept the legitimacy of bottom-up approaches and to embrace community participation in biodiversity management, (2) seeing local organizations empowered to take action and influence others, and (3) generating local trust, support and behaviour change through local benefits.

\section{Livelihoods interventions in context}

Although many projects considered livelihoods interventions as a strategic approach to reduce threats (Table 1), in very few cases $(n=5)$ were livelihoods interventions the only activity being undertaken within conservation

TABLE 3 Frequency of occurrence of different livelihoods effects (number of projects) within a sample of 34 FFI livelihoodsfocused projects.

\begin{tabular}{llc}
\hline $\begin{array}{l}\text { Livelihoods } \\
\text { effect }\end{array}$ & No. of \\
Assets & Human & $\begin{array}{c}\text { projects } \\
\text { Financial }\end{array}$ \\
& Natural & 7 \\
& Physical & 7 \\
& Social & 8 \\
Structures/processes & & 14 \\
Empowerment & & 10 \\
Outcomes & Increased income & 9 \\
& Food security & 15 \\
& Sustainable natural & 10 \\
& resource management & 14 \\
& Reduced vulnerability & 15 \\
\hline
\end{tabular}

projects. A range of other conservation activities were being implemented concurrently, the most common being awareness-raising $(n=18)$, conservation capacity building $(\mathrm{n}=18)$, and management planning $(\mathrm{n}=15)$. Less common activities included formulating conservation policy $(n=5)$, directly undertaking or supporting security patrols in protected areas $(\mathrm{n}=8)$, or direct species management $(\mathrm{n}=2)$.

\section{Discussion}

This study has unravelled the complexity in the conservation-poverty nexus across a broad geographic and thematic range of conservation projects within a single organization. Although based on reported plans and perspectives more so than on actual measures of impact, and therefore influenced to some extent by respondents' understanding and interpretation, the results still reveal much about how conservation and poverty are linked in real world project situations. Moreover, although based on the experiences of a single international conservation organization, it does represent a wide cross-section of such projects and is thus likely to reflect the spectrum of scenarios that other international conservation organizations will experience. In that sense the findings should have some resonance for the wider conservation community.

This study reveals that, even within a single project the relationship is rarely simple, and disentangling the links to determine appropriate actions is not straightforward. The real world situations described here suggest that taking account of human needs in conservation is not unreasonable and often strategically paramount. Yet this is not the same as reducing poverty. The principal questions that arise are whether and how conservation strategies really do have the potential to reduce poverty and, depending on the answer, what conservation organizations should do about it. 
TABLE 4 Examples of demonstrated livelihoods impacts and associated conservation outcomes in selected FFI livelihoods-focused projects. Reducing vulnerability and increasing empowerment are common features of successful projects. In that regard, addressing immediate local needs and building on existing livelihoods and traditional practices yields results more quickly than attempting to develop unfamiliar and unproven alternative livelihoods. Ensuring a tangible link between livelihoods benefits and conservation is important.

\begin{tabular}{|c|c|c|}
\hline Project & Livelihoods impacts & Conservation outcomes \\
\hline $\begin{array}{l}\text { Developing participatory } \\
\text { forest management in } \\
\text { southern Tanzania }\end{array}$ & $\begin{array}{l}\text { Improved knowledge, awareness \& } \\
\text { local institutions enabling communities } \\
\text { to assert their tenurial rights \& increase } \\
\text { the price paid for sustainably harvested } \\
\text { logs by } 200 \%\end{array}$ & $\begin{array}{l}\text { Community members are patrolling } \\
\text { the forest \&, for the first time, are } \\
\text { turning away illegal loggers \& imposing } \\
\text { fines on their own members for } \\
\text { misdemeanours. }\end{array}$ \\
\hline $\begin{array}{l}\text { Enhancing livelihoods \& } \\
\text { engaging communities in } \\
\text { species \& habitat } \\
\text { conservation in the } \\
\text { Cardamom Mountains, } \\
\text { Cambodia }\end{array}$ & $\begin{array}{l}\text { Better farming techniques have more than } \\
\text { doubled rice yields, reducing vulnerability to } \\
\text { food shortages from } 7 \text { months to } 3 \text { per year. } \\
\text { Local land rights are being respected, social } \\
\text { cohesion has improved, \& support for } \\
\text { traditional non-timber forest product } \\
\text { harvesting has increased prices paid at market. }\end{array}$ & $\begin{array}{l}\text { Communities are acting to deter } \\
\text { poaching, logging \& habitat clearance. } \\
\text { The Critically Endangered Siamese } \\
\text { crocodile Crocodylus siamensis } \\
\text { population is recovering. }\end{array}$ \\
\hline $\begin{array}{l}\text { Engaging buffer zone } \\
\text { communities to support } \\
\text { protected area conservation in } \\
\text { the southern Amazon, Brazil }\end{array}$ & $\begin{array}{l}\text { Improving pasture management has improved } \\
\text { milk productivity whilst developing local } \\
\text { agricultural networks has improved access to } \\
\text { markets. Forest restoration around natural } \\
\text { springs has secured the flow of fresh water. }\end{array}$ & $\begin{array}{l}\text { Increased awareness of the value of } \\
\text { forests has increased local commitment } \\
\text { to conservation. Active forest } \\
\text { restoration \& protection in buffer zones } \\
\text { now taking place. }\end{array}$ \\
\hline
\end{tabular}

\section{Are global conservation efforts reducing poverty?}

It is clear that the activities of international conservation organizations are unlikely to make a significant impact on global poverty. Although the chronically poor are largely found in rural, forested and arid lands (Hulme \& Shepherd, 2003), the majority of the world's poor live in peri-urban areas. The threatened biodiversity and protected areas of interest to international conservation organizations in the developing world tend to be in areas of low rural population density (Redford et al., 2008) and low agricultural potential (Gorenflo \& Brandon, 2006) and where poverty may be no more acute than elsewhere in these countries (de Sherbinin, 2008).

Moreover many livelihoods-focused projects may not be about reducing poverty at all (Table 1). This is certainly true where projects are working primarily to offset the costs of conservation, where the logical conclusion is that people will be no worse off, but also by implication no better off, than if biodiversity was not being conserved. In practice the balance of trade-offs between accepting the limits on livelihoods imposed by living with wildlife, protected areas and resource restrictions, and the alternative benefits that conservation projects bring to offset those costs, is unlikely to be exact. Whether it yields a net benefit could be extremely hard to determine.

Yet this does not mean that conservation activities are irrelevant to the poor. The results of this study suggest that, at a local scale, conservation activities have the potential to make a difference where local poverty (i.e. a lack of choice) threatens biodiversity (Table 3). Giving people livelihoods choices and the potential to improve their well-being in ecologically sustainable ways is clearly beneficial but this is rarely just about alternative livelihoods providing income and jobs (Tables 2 \& 3). Ecotourism, for example, despite being amongst the highest profile alternative livelihood approaches in conservation (Agrawal \& Redford, 2006), was being promoted in $<20 \%$ of projects examined.

The majority of projects involved training and capacity building to improve food security and sustainable resource management outcomes and to strengthen and diversify livelihoods strategies. However in c. $40 \%$ of projects the focus was on improving social networks and strengthening policies and institutions to build connectedness, empowerment and voice, and thereby reduce vulnerability (Tables 3 \& 4). These are harder to conceptualize and less easily measurable, in terms of their impact on poverty, than material measures such as income and jobs.

There are many ways in which conservation activities can subtly influence the poor. Pride, happiness, feelings of responsibility, empowerment and security can all enrich well-being in ways not well captured in standard indicator frameworks like the Human Development Index (World Bank, 2008) or the Millennium Development Goals (Millennium Ecosystem Assessment, 2005). Just because they are not easy to measure does not mean that they should be ignored (Dasgupta, 2004).

Conservation can also benefit people in less obvious ways. The argument that conservation reduces poverty because biodiversity underpins human well-being through its contribution to ecosystem services such as pollination, clean air and flood control (Ash \& Jenkins, 2007) was rarely 
cited in the projects examined here (Table 1; see Swiderska et al., 2003, for similar findings). Yet as such services decline the poor suffer more than the rich because of their greater direct dependence on locally sourced ecosystem goods and services such as food, fibre, medicines and watershed protection (Shackleton et al., 2007). In many cases natural resources act as a safety net for the poor rather than a route out of poverty (Wunder, 2001) but, either way, conserving functioning natural ecosystems will benefit the poor. In contrast, conservation that focuses on particular elements of biodiversity will only benefit the poor where those elements of biodiversity are of significance in the livelihoods of the poor. As much conservation activity focuses on globally threatened species rather than locally utilized biodiversity, this is not always the case (Roe \& Walpole, in press).

\section{How should conservation organizations respond?}

The diversity of rationales, approaches and outcomes is a consequence of the varied contexts in which biodiversity exists and conservation operates. Understanding why to engage with local communities will help practitioners to identify how to do so, and what the goals should be. In that sense it is important for the poverty-conservation linkages and rationales to be made explicit. This will help in communicating honestly with partners, donors, and critics about project goals, and ultimately will ensure greater clarity that will improve conservation actions.

In terms of actions, some key themes emerge. Often, addressing immediate needs such as food security rather than income, and strengthening or building on existing, familiar livelihood options before introducing alternatives, is a good place to start. These are the areas where FFI's projects have generally had most demonstrable impact (Table 4). It is also clear from project evaluation reports that training, social network development (including local institutions and access to markets), partnership development, and mediation are very important elements of livelihoods-focused projects. The skills and experience to deliver these won't all be available within conservation organizations but we must know where to look to find them.

Where commercial livelihoods are being developed an understanding of markets and enterprise development is critical but often lacking. Although $<50 \%$ of projects included market-based income generation, the better performing ones were those with commercial expertise built in (Walpole \& Thouless, 2005; for a more detailed discussion of experiences with enterprise development see FFI, 2008b).

In our experience, however, and as revealed in the project reports examined here, most demonstrable outcomes were achieved not through enterprise development but through other forms of empowerment. In that sense supporting people-centred policy development and building staff and partner capacity in social impact assessment and other tools is relevant. However, four important caveats, arising either from the results of the study or from workshops and discussions during the course of the study, should frame the way that the relationship between conservation and poverty reduction is viewed.

Firstly, the immediacy of the human issues and the difficulty of identifying conservation impacts in the shortterm can lead to mission creep, whereby addressing human needs becomes a de facto project goal, but it is important not to lose sight of conservation goals when focusing on what projects are achieving in livelihoods terms. Although community-based livelihoods and local empowerment approaches generally take longer to mature and to yield tangible results, it should still be possible to measure some form of biodiversity threat reduction in the shortto medium-term (Table 4; Salafsky \& Margoluis, 1999). Regularly reviewing the rationale and impacts of the approach and adapting actions accordingly will help to keep it on track.

Secondly, conservation organizations are not the only bodies working in this area, and we need to be working much harder to convince the humanitarian and development sectors to take notice of environment and biodiversity more clearly than they currently do. This means working more closely in partnership with these sectors (Walpole, 2006; Adams, 2007) but also requires stronger rationales for why biodiversity loss is an important issue for them to tackle.

Thirdly, livelihoods-focused interventions are only part of the conservation toolkit alongside direct site and species management, education, capacity building, policy and legislative initiatives and research. In all the projects examined here, on average 1-2 of these other activities were being employed besides livelihoods-focused activities. In these projects the achievement of conservation goals does not rely solely on livelihoods interventions and poverty reduction but on multiple approaches. Success, for conservation or poverty reduction, is not well captured by focusing on simple cause and effect models.

Fourthly, whilst it is clear from this study that community engagement is widespread, this does not mean that focusing on poverty or poverty reduction is applicable in all conservation situations. In some, site and species management and protection may be more appropriate approaches than livelihoods, education and empowerment. The answer will be context specific and conservation should not be viewed, enacted or judged solely through the lens of poverty reduction.

\section{Conclusions and recommendations}

Conservation and poverty reduction are different societal goals that in particular contexts may come together in mutually supportive or conflicting ways. Relationships 
between poverty and conservation are complex but this is not always manifest in the wider debate. Conservation organizations need to distance themselves from the generic debate about whether conservation actions are beneficial or detrimental to poor people, and likewise from oversimplified attempts to prove or disprove assumptions of causality between poverty reduction and conservation.

Conservation organizations have been criticized for their social record, and at the same time are expected to contribute positively to poverty reduction efforts. This study of a sample of conservation projects has shown that there is widespread social responsibility and a wide range of potential and actual benefits for the poor. On the one hand conservation organizations could do more to promote the wider societal benefits of their activities, whether direct or indirect, tangible or intangible, passive or active, short-term or long-term. On the other hand, if they are claiming to be generating benefits then they need to be sure that they can demonstrate them. To negotiate the minefield, address the critics, and do justice to their achievements without resorting to unsubstantiated rhetoric, conservation organizations could adopt the following recommendations:

- Be clear in each specific context about why they are engaging with livelihoods or poverty reduction, and how poverty and conservation interact, both positively and negatively.

- Be clear about which elements of biodiversity and which elements of poverty they are dealing with in each case.

- Be clear about who they are dealing with and why, and who will benefit or not, considering potential trade-offs. If acting to offset costs, it is important to know who the poor are and how they are affected by conservation activities.

- Be clear about underlying assumptions, and test them wherever necessary.

- Be clear about the time-scale over which benefits and costs may ensue. There are not always short-term increases in income. When dealing with issues such as sustainable use, reduced vulnerability, and increased resilience there may be short-term tangible costs to achieve longer term but less tangible security.

- Be clear about where livelihoods interventions fit within broader conservation strategies in each particular case. Reductionist causal-chain arguments focused on single types of conservation activity mask the complexity of conservation and the effects and importance of other areas of a strategy in achieving goals.

- Attempt to measure and demonstrate the broader range of possible impacts for people, rather than just focusing on one or two simple, tangible, material examples.

There is a range of assessment, research, monitoring and evaluation tools available to assist these tasks, including stakeholder analyses, social risk assessments, poverty map- ping, and both indicator-based and non-indicator-based approaches to monitoring and evaluation (Wilder \& Walpole, 2008). A lot can be learned from the development sector in this regard (Walpole et al., 2007), and conservation scientists of every discipline and persuasion should be devoting their efforts to further our understanding and improve our impact in situations where poverty and conservation coincide.

\section{Acknowledgements}

This paper has benefited from the efforts and inputs of a great many people, and in particular Bill Adams, Ros Aveling, Barney Dickson, Abigail Entwistle, Jon Hutton, Lydia Richardson and all those FFI staff and partners who provided thoughts and perspectives on this topic. FFI's Biodiversity \& Human Needs programme is supported by DGIS, the Directorate General of International Cooperation of the Dutch Ministry of Foreign Affairs, through the 4-year project Resources for Improved Livelihoods.

\section{References}

Adams, W.M. (2007) Thinking like a Human: social science and the two cultures problem. Oryx, 41, 275-276.

Adams, W.M., Aveling, R., Brockington, D., Dickson, B., Elliott, J., Hutton, J. et al. (2004) Biodiversity conservation and the eradication of poverty. Science, 306, 1146-1149.

Agrawal, A. \& Redford, K. (2006) Poverty, Development and Biodiversity Conservation. Shooting in the Dark? WCS Working Paper No. 26, Wildlife Conservation Society, New York, USA.

Ash, N. \& Jenkins, M. (2007) Biodiversity and Poverty Reduction: The Importance of Ecosystem Services. UNEP-World Conservation Monitoring Centre, Cambridge, UK.

Brockington, D. \& Schmidt-Soltau, K. (2004) The social and environmental impacts of wilderness and development. Oryx, 38 , 140-142.

Chapin, M. (2004) A challenge to conservationists. World Watch, November/December 2004, 17-31.

Dasgupta, P. (2004) Human Wellbeing and the Natural Environment. Oxford University Press, Oxford, UK.

De Sherbinin, A. (2008) Is poverty more acute near parks? An assessment of infant mortality rates around protected areas in developing countries. Oryx, 42, 26-35.

DFID (2000) Sustainable Livelihoods Guidance Sheets. Department for International Development, London, UK.

FFI (2006) The Case for Integrating Conservation and Human Needs. Livelihoods and Conservation in Partnership Series No. 1. Fauna \& Flora International, Cambridge, UK.

FFI (2008a) Fauna \& Flora International. Http://www.fauna-flora.org [accessed 2 July 2008].

FFI (2008b) The Role of Enterprise Development in Conservation. Livelihoods and Conservation in Partnership Series No. 5. Fauna \& Flora International, Cambridge, UK.

Gorenflo, L.J. \& Brandon, K. (2006) Key human dimensions of gaps in global biodiversity conservation. Bioscience, 56, 723-731.

Hulme, D. \& Shepherd, A. (2003) Conceptualising chronic poverty. World Development, 31, 399-402.

Kaimowitz, D. \& Sheil, D. (2007) Conserving what and for whom? Why conservation should help meet basic needs in the tropics. Biotropica, 39, 567-574. 
Kiss, A. (2004) Is community-based ecotourism a good use of biodiversity conservation funds? Trends in Ecology \& Evolution, 19, 232-237.

Lockwood, M., Worboys, G. \& Kothari, A. (2006) Managing Protected Areas: A Global Guide. Earthscan, London, UK.

Mapendembe, A., Thomas, D. \& Dickson, B. (2008) Conservation \& Poverty: A Review of Existing Commitments. FFI and BirdLife International, Cambridge, UK.

Millennium Ecosystem Assessment (2005) Ecosystems and Human Well-being: Biodiversity Synthesis. Island Press, Washington, DC, USA.

Nadkarni, M.V. (2000) Poverty, environment, development a many-patterned nexus. Economic and Political Weekly, 35, 11841190.

OECD (2001) The DAC Guidelines: Poverty Reduction. Organisation for Economic Cooperation and Development, Paris, France.

Redford, K.H., Levy, M.A., Sanderson, E.W. \& de Sherbinin, A. (2008) What is the role for conservation organizations in poverty alleviation in the world's wild places? Oryx, 42, 516-528.

Robinson, J.G. (2006) Conservation biology and real world conservation. Conservation Biology, 20, 658-669.

Roe, D. (2008) The origins and evolution of the conservationpoverty debate: a review of key literature, events and policy processes. Oryx, 42, 491-503.

Roe, D. \& Elliott, J. (2004) Poverty reduction and biodiversity conservation: rebuilding the bridges. Oryx, 38, 137-139.

Roe, D. \& Elliott, J. (2005) Poverty-Conservation Linkages: A Conceptual Framework. Poverty \& Conservation Learning Group, International Institute for Environment and Development, London, UK.

Roe, D. \& Elliott, J. (2006) Pro-poor conservation: the elusive win-win for conservation and poverty reduction? Policy Matters, $14,53-63$.

Roe, D. \& W Alpole, M.J. (in press) Whose value counts? Trade-offs between biodiversity conservation and poverty reduction. In Trade-offs in Conservation: Deciding What to Save (eds N. LeaderWilliams, W.M. Adams \& R. Smith). Blackwells, Oxford, UK.

Salafsky, N. \& Margoluis, R. (1999) Threat reduction assessment: a practical and cost-effective approach to evaluating conservation and development projects. Conservation Biology, $13,830-841$.

Sanderson, S. \& Redford, K. (2003) Contested relationships between biodiversity conservation and poverty alleviation. Oryx, $37,1-2$.

Sanderson, S. \& Redford, K. (2004) The defence of conservation is not an attack on the poor. Oryx, 38, 146-147.

Shackleton, C.M., Shackleton, S.E., Buiten, E. \& Bird, N. (2007) The importance of dry woodlands and forests in rural livelihoods and poverty alleviation in South Africa. Forest Policy and Economics, 9, 558-577.

Sunderlin, W.D., Angelsen, A., Belcher, B., Burgers, P., Nasi, R., Santoso, L. \& Wunder, S. (2005) Livelihoods, forests, and conservation in developing countries: an overview. World Development, 33, 1383-1402.
Swiderska, K., Roe, D., Maganga, F. \& Wilder, L. (2003) Voices from the South: The Role of Civil Society in Linking Biodiversity Conservation and Poverty Reduction. International Institute for Environment and Development, London, UK.

Terborgh, J. (2004) Reflections of a scientist on the World Parks Congress. Conservation Biology, 18, 619-620.

Upton, C., Ladle, R., Hulme, D., Jiang, T., Brockington, D. \& Adams, W.M. (2008) Are poverty and protected area establishment linked at a national scale? Oryx, 42, 19-25.

Walpole, M.J. (2006) Partnerships for conservation and poverty reduction. Oryx, 40, 245-246.

Walpole, M.J. \& Thouless, C.R. (2005) Increasing the value of wildlife through non-consumptive use. In People and Wildlife: Conflict or Coexistence? (eds R. Woodroffe, S. Thirgood \& A. Rabinowitz), pp. 122-139. Cambridge University Press, Cambridge, UK.

Walpole, M.J., Wilder, L., Granziera, A., Thomas, D. \& Elliot T, J. (2007) Measuring the Impact of Livelihoods Initiatives in the Conservation Context. Fauna \& Flora International/BirdLife International/African Wildlife Foundation, Cambridge, UK.

Wilder, L. \& WAlpole, M.J. (2008) Measuring social impacts in conservation: experience of using the Most Significant Change method. Oryx, 42, 529-538.

WORLD BANK (2008) World Development Indicators. The World Bank, Washington, DC, USA.

Wunder, S. (2001) Poverty alleviation and tropical forests - what scope for synergies? World Development, 29, 1817-1833.

WWF (2006) Species and People: Linked Futures. WWF International, Gland, Switzerland.

\section{Appendix}

The appendix for this article is available online at http:// journals.cambridge.org

\section{Biographical sketches}

Matt Walpole specializes in interdisciplinary approaches to conservation research and practice in the developing world, having worked on human-wildlife conflict mitigation and the role of ecotourism as a conservation and development tool. From 2004 he directed FFI's Biodiversity and Human Needs programme, exploring wider links between poverty and conservation and developing staff and organizational capacity to deliver multiple benefits from FFI's field programmes. In 2008 he joined the Ecosystem Assessment programme at the UNEP-World Conservation Monitoring Centre. Lizzie Wilder worked with the IUCN Sustainable Use Specialist Group before joining FFI's Biodiversity and Human Needs programme in 2004. She focuses on promoting understanding and better practice around the issues of conservation and poverty alleviation, with a particular interest in socio-economic monitoring and evaluation. 